\title{
Air Pollution in Bangladesh and Its Consequences
}

\author{
Salamat Khandker ( $\sim$ drsalamat@daffodilvarsity.edu.bd) \\ Daffodil International University \\ ASM Mohiuddin \\ University of Dhaka: Dhaka University \\ Sheikh Akhtar Ahmad \\ Bangladesh University of Health Sciences \\ Alice McGushin \\ London School of Hygiene and Tropical Medicine Faculty of Public Health and Policy \\ Alan Abelsohn \\ University of Toronto
}

\section{Research Article}

Keywords: Air Pollution, Air Quality, Respiratory Diseases, Bangladesh

Posted Date: February 17th, 2022

DOI: https://doi.org/10.21203/rs.3.rs-1184779/v1

License: @ (i) This work is licensed under a Creative Commons Attribution 4.0 International License. Read Full License 


\section{Abstract}

This study aims to review the literature about air pollution, both outdoor and household, and its health consequences in Bangladesh. We searched articles in March 2021 using the PubMed/Scopus database, government publications, NGO report and reports of DoE. As a result, peer-reviewed published documents with analytical data and results were retrieved. We also reviewed studies related to ambient and household air quality, the sources of air pollution, the health and economic implications, and the role of NGOs and Govt. of Bangladesh. The sources of ambient air pollution in Bangladesh include Anthropogenic origins like the burning of fossil fuel, coal, wood, open burning of waste or agricultural residues, emission from motor vehicles and industries, use of biomass fuel for cooking, and transboundary air pollution; and Natural sources like windblown dust, sea spray, forest fires, and methane gas emitted by animals. Brick kilns, surface dust, and vehicle emissions contribute about $85.0 \%$ of local air pollution in Dhaka, the largest urban area. The contribution from transportation is aggravated by traffic congestion, contaminated fuels, including leaded fuels, two-stroke auto-rickshaws, overloading, and the dust generated due to friction with the roadways. Industries inside cities and brick kilns surrounding the town are also significant contributors. In recent years, the air pollution of Dhaka city has worsened, causing adverse health effects and environmental degradation. The government response has included eliminating the leaded fuel, initiating the use of Compressed Natural Gas (CNG), and phasing out the two-stroke auto-rickshaw, replacing them with CNG driven auto rickshaw. It also implemented and updated regulations, formulated policies and strategic plans.

\section{Introduction}

The World Health Organization (WHO) member states adopted in 2015 a resolution to address adverse health effects of air pollution and declared air pollution as a public health emergency (WHO, 2016). In 2019 over $90 \%$ of the world's population were exposed to an annual average PM2.5 concentration that exceeded the WHO air quality guideline value of $10 \mu \mathrm{g} / \mathrm{m} 3$, and air pollution became the fourth risk factor in 2019 for premature death worldwide. It is estimated that air pollution caused 6.67 million deaths worldwide in 2019, nearly 12\% of the total global deaths (SOGA, 2020a). In Bangladesh, there were 123,000 deaths attributable to air pollution in 2017, increasing to 173,500 in 2019 (SOGA, 2019). The proportion of the elderly population has increased in the last decades due to increased life expectancy in Bangladesh, contributing to an additional risk factor for air pollution-related deaths. Unplanned urbanization and pollutants of mega construction works are significant contributors to air pollution in Dhaka, the largest city (IQAir, 2020a). Bangladesh has one of the highest levels of exposure to PM2.5, ranking ninth among the top ten countries with the highest level of PM 2.5 in outdoor air (SOGA, 2020b).

\section{Method}

This study aimed to review the literature about outdoor and household air pollution and its health consequences in and around the major city areas of Bangladesh. A search of articles was conducted in March 2021 using the PubMed/Scopus database, Bangladesh government's publications, DoE reports and report of national and international organizations. Peer-reviewed published documents with analytical data and results were retrieved. We retrieved studies related to ambient and household air quality, the sources of air pollution, the health and economic implications, and the role of NGOs and Govt. of Bangladesh. Published current reports and appropriate dissertations were also considered. Our search yielded more than 100 documents related to air pollution in Bangladesh and other Asian countries. Irrelevant documents and studies published only in the abstract form were excluded. Articles published from 2010 until 2020 were selected.

\section{Background History Of Air Pollution Activities In Bangladesh}

\subsection{Governance}

The Air Pollution Control Board (APCB) started air monitoring activities in Bangladesh under the environment pollution project in 1977. In 1985 the APCB was renamed the Department of Environment Pollution Control (DEPC), and in 1989, DEPC was restructured and renamed the Department of Environment (DoE). The Director-General of the Department of Environment (DGDoE) is responsible for overseeing the activities of the DoE (Background DOE), with a Director Air Pollution in charge of air pollution issues (Organogram- DOE).

\subsection{Air Pollution Monitoring in Bangladesh}

1n 1997, the Department of Environment (DoE) of the Government of Bangladesh started measuring total Suspended Particles (TSP) in different cities as part of their regulatory activity. The DOE launched the Air Quality Management Project (AQMP) in 2000 with assistance from the World Bank. In 2002, the DoE started measuring $\mathrm{PM}_{10}$ and $\mathrm{PM}_{2.5}$ and the other criteria pollutant, Oxides of Nitrogen (NO), Carbon Monoxides (CO), Sulfur dioxide (SO ${ }_{2}$ ), and Ozone $\left(\mathrm{O}_{3}\right)$, as well as methane and non-methane hydrocarbons (NMHCs) for regulatory purposes (BGD, 1995; CASE, 2018). The AQMP has been renamed the Clean Air and Sustainable Energy (CASE) project. The Bangladesh Air Quality Monitoring (AQM) network provides reliable information to the authorities and public about the air quality in the country's most populous cities (CASE, 2019).

At present, there are 16 Continuous Air Monitoring Stations (CAMS) under DoE supported CASE project (Fig. 1) with 24-hour continuous monitoring of NO, $\mathrm{CO}, \mathrm{SO}_{2}, \mathrm{O}_{3}, \mathrm{PMs}$, and methane, and non-methane hydrocarbons (NMHCs). Data from network stations are transferred to a central data center at the DoE office in Dhaka, where the database is maintained with quality control, evaluation, validation, and statistical analysis. Data are then stored in the final database for further analysis, reporting, presentations, and future use. Precision, accuracy, representativeness, and comparability of data are monitored continuously with DoE maintained Standard Operating procedures (SOP) (CASE, 2018). Other air monitoring stations include the DoE campus, Agargaon, BAEC Campus, Ramna, BITAC campus, and Tejgaon, run by DoE, the US-Embassy in Dhaka with its own continuous air monitoring station (CAMS) at Baridhara, a station in Satkhira of Khulna Division run by The Council of South Asian Co-operative Environment Program (SACEP) (SACEP, 1998), and the 
Bangladesh Atomic Energy Commission (BAEC), University of Dhaka (DU), Bangladesh University of Engineering and Technology (BUET), International Center for Diarrheal Disease Research, Bangladesh (ICDDR, B) have their air quality monitoring systems. There is also a regional satellite air quality monitoring system in Bangladesh, and NASA provides the measurements of nitrogen dioxide for Dhaka (NASA, 2021).

Since 2014, 12 cities (8 divisional headquarter plus Gazipur, Narayangonj, Narshindi, and Savar) have been informed about the daily AQI levels through radio, TV, and internet, with messages in the Bangla and the English languages. In addition, data of 15 CAMS are analyzed, and people are advised to take health-related precautionary measures if AQI rises above 200.

The Department of Soil, Water \& Environment of the University of Dhaka has its air monitoring station. Prof. Dr. Abdus Salam is leading the research activities on air pollution, including transboundary sources of air pollution in Dhaka city (Research \& Publication-UD, 2021). Department of Mechanical Engineering has been researching the emission of pollutants from motor vehicles and roadside construction (Rahman, 2021). Bangladesh Atomic Energy Commission (BAEC) provides technical support, develops policy documents, conducts applied research, and field tests new technologies to reduce air pollution in Bangladesh, e.g., IDCOL report 2017 (IDCOL, 2017).

\section{Major Sources Of Outdoor Air Pollution}

The sources of ambient air pollution in Bangladesh include both anthropogenic and natural. Anthropogenic sources include burning fossil fuel, including coal, wood, open burning of waste or agricultural residues, emission from motor vehicles, power generation and industries, biomass fuel for cooking, and transboundary air pollution. The Natural sources include windblown dust, sea spray, and forest fires (Natural air pollution sources). Natural sources mainly remain localized, while anthropogenic sources are more widely distributed and exceed natural sources (WHO, 2018a). For example, a 2014 report in Dhaka showed that brick kilns, surface dust, and vehicle emissions contribute about $85 \%$ of local air pollution (William, 2020). Other sources of air pollution include open landfills, incineration of plastic waste, and industrial processes (William, 2020). We will discuss some of the major sources of ambient air pollution in more detail.

\subsection{Brick Kilns}

There are 7902 brick kilns throughout the country (CASE, 2018), with about 1000-1200 around Dhaka. Due to rapid industrial growth and urbanization, the number of brick kilns has increased. This contributes to 58\% of air pollution in Dhaka (Begum et al. 2018; Rahman et al. 2019). In the kilns, coal and wood are used to burn the bricks. Approximately 2.2 million tons of coal are burned, yielding tons of PM, sulfur dioxide, carbon monoxide, volatile organic compounds, and other toxic substances such as furans and dioxin (DOE, 2019a). This emission could be substantially reduced if natural gas replaced coal and wood in brick kiln industries (Begum et al., 2018).

\section{2. Motor Vehicles}

The number of motor vehicles is increasing rapidly in Bangladesh, from 1.49 million in 2010 to 4.44 million in 2020 (BRTA-Number of registered vehicles). The majority of these vehicles are reconditioned or old and lack proper maintenance. Congested traffic, bad parking management, contaminated fuels, overloading, and the dust generated due to frictions with the roadways contribute to air pollution (DOE, 2019a). 30-50\% of PM collected from different areas of Dhaka city are fine particles generated from transport-related sources (Begum et al., 2010), especially from diesel buses and trucks (45\%) and autorickshaws (40\%) (DOE, 2019a). Petrol-fueled light-duty vehicles (cars/ vans) and auto-rickshaws contribute 85\% of total carbon monoxide (CO), while diesel-fueled buses and trucks contribute $84 \%$ of total Nitrogen oxides $\left(\mathrm{NO}_{\mathrm{x}}\right)$. In the late nineties, Dhaka was the most polluted city globally, including having the highest levels of lead in the air ( 463 nanograms $/ \mathrm{m}^{3}$ ). The government banned leaded gasoline in 1999, followed by an embargo on the twostroke engine auto-rickshaws. As a result, the lead concentration in the air was reduced (Begum and Hopke, 2018).

\subsection{Power Plants:}

Eighty percent (80\%) of the power generation in Bangladesh is gas-based, while the remaining $20 \%$ is coal, liquid, and furnace oil-based. Combustion of coal during electrical utilities contributes about $70 \%$ of sulfur dioxide $\left(\mathrm{SO}_{2}\right)$ and $30 \%$ of nitrogen oxides (NOx) (Arnab et al., 2013). One hydraulic power station, the Barapukuria thermal power plant, with $\mathrm{SO}_{2}, \mathrm{NOx}$, and PM emissions in allowable levels (Masud et al., 2014). Bangladesh has achieved significant economic progress and has reached the three graduation criteria set by the United Nations Committee for Development Policy (UNCDP) in 2018 and 2021 (Mustafizur, 2021). As a result, many significant infrastructure projects, like roads, rail, bridges, and large buildings, have been undertaken. These projects have led to environmental degradation, dust production, and displacement of communities without proper safety and environmental precautions (Nahar et al., 2021). The road dust and soil dust from these construction projects are significant contributors to air pollutants, especially PM, during the dry season (DOE, 2018, 2019).

\subsection{Trans-boundary air pollution}

Bangladesh is surrounded on three sides by India, a highly polluted country. Transboundary pollutants typically originate in North-Western India, West Bengal, Nepal, and the neighboring areas, with pollutants traveling from 200 to $500 \mathrm{~km}$ across the border to Bangladesh. The transboundary PM from India's coal-burning contributes to $40 \%$ of the air pollution in Bangladesh (Sakib, 2021; Rana et al. 2016), especially between November to January (Rana et al., 2016). In addition, the burning of agricultural fields in India in October and November emits smoke plumes that blanket almost the whole of IndoGangetic plain (IGP) from the West to the East, including Bangladesh (Singh and Kaskaoutis, 2014), and can even be transported through Himalayan foothills (Bonasoni et al. 2010) 


\section{Outdoor Air Quality In Bangladesh}

We discuss outdoor air quality in two ways. Firstly, we use the AQI to report specific air quality data. Then, finally, we report air quality trends.

\subsection{The Bangladesh Air Quality Index (AQI)}

In Bangladesh, the AQI is based on five criteria pollutants: Particulate Matter (PM10 and PM2.5), Nitrogen Dioxide NO2, carbon Monoxide CO, Sulfur Dioxide SO, and Ozone $\left(\mathrm{O}_{3}\right.$ ). The Bangladesh government has adopted the WHO guideline values, and the Air Quality Index (AQI) is based on the government adopted guidelines for these five pollutants:

Table-1: National Ambient Air Quality Standards for Bangladesh

\begin{tabular}{|c|c|c|}
\hline Name of pollutant & $\begin{array}{l}\text { Quality maintaining } \\
\text { criteria }\end{array}$ & Fulfillment of quality criteria \\
\hline \multirow[t]{2}{*}{ Carbon monoxide (CO) } & $10 \mathrm{mg} / \mathrm{m}^{3}(9 \mathrm{ppm})$ & Average in 8 hours. Not to be exceeded more than once per year \\
\hline & $40 \mathrm{mg} / \mathrm{m}^{3}(35 \mathrm{ppm})$ & Average in 1 hour. Not to be exceeded once a year \\
\hline \multirow{2}{*}{$\begin{array}{l}\text { Particulate Matter } 10 \\
\left(\mathrm{PM}_{10}\right)\end{array}$} & $50 \mu \mathrm{g} / \mathrm{m}^{3}$ & Annual average. The yearly arithmetic mean should be less than or equal to $50 \mathrm{ug} / \mathrm{m}^{3}$ \\
\hline & $150 \mu \mathrm{g} / \mathrm{m}^{3}$ & $\begin{array}{l}24 \text { hours on average. The } 24 \text { - hour average of } 150 \mu \mathrm{g} / \mathrm{m}^{3} \text { should be equal to or less than } 1 \text { per } \\
\text { calendar year. }\end{array}$ \\
\hline \multirow{2}{*}{$\begin{array}{l}\text { Particulate Matter } 2.5 \\
\left(\mathrm{PM}_{2.5}\right)\end{array}$} & $15 \mu \mathrm{g} / \mathrm{m}^{3}$ & Annual average. The yearly arithmetic mean should be less than or equal to $15 \mathrm{ug} / \mathrm{m}^{3}$ \\
\hline & $65 \mu \mathrm{g} / \mathrm{m}^{3}$ & $\begin{array}{l}24 \text { hours on average. The } 24 \text { - hour average should be less than } 65 \mu \mathrm{g} / \mathrm{m}^{3} \text { throughout the } \\
\text { calendar year. }\end{array}$ \\
\hline \multirow[t]{2}{*}{ Ozone $\left(\mathrm{O}_{3}\right)$} & $235 \mu \mathrm{g} / \mathrm{m}^{3}(0.12 \mathrm{ppm})$ & $\begin{array}{l}1 \text { hour. The maximum hourly average should not exceed } 0.12 \mathrm{ppm} \text { for more than one day in a } \\
\text { calendar year. }\end{array}$ \\
\hline & $157 \mu \mathrm{g} / \mathrm{m}^{3}(0.08 \mathrm{ppm})$ & 8 hours average should not exceed 0.08 ppm in 24 hours \\
\hline \multirow[t]{2}{*}{ Sulfur-di-oxide $\left(\mathrm{SO}_{2}\right)$} & $80 \mu \mathrm{g} / \mathrm{m}^{3}(0.03 \mathrm{ppm})$ & Annual concentration should not exceed $80 \mu \mathrm{g} / \mathrm{m}^{3}(0.03 \mathrm{ppm})$ \\
\hline & $365 \mu \mathrm{g} / \mathrm{m}^{3}(0.14 \mathrm{ppm})$ & The annual average should not exceed. \\
\hline Lead (PB) & $0.5 \mu \mathrm{g} / \mathrm{m}^{3}$ & The annual average should not exceed \\
\hline NOx & $\begin{array}{l}100 \mu \mathrm{g} / \mathrm{m}^{3}(0.053 \\
\mathrm{ppm})\end{array}$ & The annual average should not exceed \\
\hline
\end{tabular}

The AQI in Bangladesh is reported on a scale as good 0-50, moderate 51-100, Cautious 101-150, unhealthy 151-200, very unhealthy 200-300, and highly unhealthy 301-500. Data is collected from Continuous Air Monitoring Stations (CAMS) in 12 cities throughout Bangladesh, as discussed above (CASE, 2018) (Figure-1).

Table-2 shows that, in 2020 , based on the AQI, the air quality averaged across the country was unhealthy to highly unhealthy on an average of 161 days per year, moderate on an average of 145 , and good 59 days per year. The average number of days of unhealthy to extremely unhealthy air quality per year was 210 days in Dhaka, the country's most polluted city (IQAir, 2020b), 176 days in Narayanganj, and 187 days in Gazipur, the middle part of Bangladesh. On the other hand, the air quality of Sylhet, the northeast part of the country, was considerably better.

The air quality in all the reported areas had seasonal variations, according to CAMS data Figure-2. Due to high PM concentrations, the air quality was inferior from November to April. However, the air quality was good to moderate from May to October, with low PM concentrations. From May to October, windstorms and rainfall contributed to improving air quality in the city. The weather is favorable for raw brick manufacturing and burning during the winter months, contributing to significant pollution in Dhaka. For example, From November 2013 to April 2014, PM concentrations in Dhaka were found 7-8 times higher than the WHO guideline, $50 \mathrm{ug} / \mathrm{m} 3$ for PM10 and $15 \mathrm{ug} / \mathrm{m} 3$ for PM2.5 (CASE, 2018).

Table -2: Average day in the year of AQI category in different areas of Bangladesh from 2013 to 2017 (DOE, 2019a) 


\begin{tabular}{|llllll|}
\hline Area & \multicolumn{4}{l}{ The average number of days in a year } & \\
\cline { 2 - 5 } & AQI $\mathbf{5} \mathbf{5 0}$ & AQI $\mathbf{5 1 - 1 0 0}$ & AQI 101-200 Unhealthy & AQI 201-300 & AQI >300 \\
& Good & Moderate & & Very unhealthy & Extremely unhealthy \\
\hline Dhaka & 27 & 128 & 118 & 33 & 59 \\
\hline Gazipur & 41 & 137 & 93 & 38 & 56 \\
\hline Narayangonj & 42 & 147 & 76 & 34 & 66 \\
\hline Chittagong & 47 & 165 & 94 & 35 & 24 \\
\hline Sylhet & 61 & 185 & 94 & 21 & 4 \\
\hline Rajshahi & 153 & 108 & 71 & 22 & 11 \\
\hline Barisal & 45 & 144 & 107 & 39 & 30 \\
\hline Average & 59 & 145 & 93 & 32 & 36 \\
\hline
\end{tabular}

AQI $\leq 50$ Good, AQI 51-100 Moderate, AQI 101-200 Cautious to Unhealthy, AQI 201-300 Very Unhealthy, AQI >300 Extremely Unhealthy

\subsection{Air quality data}

Table -3 shows the annual mean concentrations of $\mathrm{PM}_{10}$ and $\mathrm{PM}_{2.5}$ in cities across Bangladesh with an average of $146.9 \mu \mathrm{g} / \mathrm{m}^{3}$ and $85.6 \mu \mathrm{g} / \mathrm{m}^{3}$, respectively, and the levels in the main cities. Again, Narayangonj was the most polluted city in Bangladesh, having $\mathrm{PM}_{10} 203.3 \mu \mathrm{g} / \mathrm{m}^{3}$ and $\mathrm{PM}_{2.5} 108.0$ $\mu \mathrm{g} / \mathrm{m}^{3}$.

Table-3: Annual mean concentrations of $\mathrm{PM}_{10}$ and $\mathrm{PM}_{2.5}$ in different cities of Bangladesh from 2013 to 2017 (DOE, $\left.2019 \mathrm{a}\right)$.

\begin{tabular}{|lll|}
\hline City & $\mathrm{PM}_{10}\left(\mu \mathrm{g} / \mathrm{m}^{3}\right)$ & $\mathbf{P M}_{2.5}\left(\mu \mathrm{g} / \mathrm{m}^{3}\right)$ \\
\hline WHO guideline & 50 & 15 \\
\hline Dhaka & 155.8 & 86.1 \\
\hline Gazipur & 161.3 & 100.7 \\
\hline Narayangonj & 203.3 & 108.0 \\
Chittagong & 132.2 & 78.7 \\
\hline Sylhet & 102.5 & 54.6 \\
\hline Barisal & 126.7 & 85.6 \\
\hline Overall & 146.9 & 85.6 \\
\hline
\end{tabular}

In Dhaka, for example, $\mathrm{PM}_{2.5}$ and $\mathrm{PM}_{10}$ exceeded the National Ambient Air Quality Standard (NAAQS) limit on $72 \%$ and $40 \%$ of the total studied days, respectively. In comparison, $\mathrm{O}_{3}$ exceeded $1.7 \% \mathrm{SO}_{2} 0.38 \%$ of days, and $\mathrm{CO}_{2} 0.32 \%$ of days (Rahman et al. 2019).

Table-4: Five years (2013-2017) mean concentrations of PMs and Gaseous Pollutants in selected CAMS during Winter, Pre-monsoon, Monsoon, and Postmonsoon (DOE, 2019a). 


\begin{tabular}{|c|c|c|c|c|c|c|}
\hline Pollutants & Districts & Winter & Pre-monsoon & Monsoon & Post-monsoon & Average \\
\hline $\mathrm{PM}_{2.5}$ & Darus Salam & 175.8 & 75.1 & 32.8 & 89.3 & 85.8 \\
\hline$\left(\mu \mathrm{g} / \mathrm{m}^{3}\right)$ & Narayonganj & 203.2 & 63.1 & 26.3 & 103.2 & 94.4 \\
\hline NAAQS-65 & Gazipur & 167.5 & 69.7 & 27.4 & 85.7 & 83.4 \\
\hline $\mathrm{PM}_{10}$ & Darus Salam & 280.3 & 145.2 & 64.5 & 158.1 & 154.9 \\
\hline$\left(\mu \mathrm{g} / \mathrm{m}^{3}\right)$ & Narayonganj & 358.0 & 164.1 & 86.0 & 214.3 & 195.3 \\
\hline NAAQS-150 & Gazipur & 257.3 & 131.6 & 50.6 & 142.0 & 139.1 \\
\hline $\mathrm{SO}_{2}(\mathrm{ppb})$ & Darus Salam & 18.9 & 10.9 & 5.9 & 7.0 & 10.9 \\
\hline \multirow[t]{2}{*}{ NAAQS-140 } & Narayonganj & 16.0 & 9.5 & 3.4 & 7.4 & 8.8 \\
\hline & Gazipur & 15.7 & 15.6 & 8.9 & 5.9 & 12.2 \\
\hline $\mathrm{NO}_{2}(\mathrm{ppb})$ & Darus Salam & 28.1 & 15.4 & 7.8 & 20.3 & 16.9 \\
\hline \multirow[t]{2}{*}{ NAAQS-53 } & Narayonganj & 18.8 & 10.2 & 6.0 & 16.3 & 12.3 \\
\hline & Gazipur & 9.0 & 3.9 & 5.4 & 6.3 & 6.1 \\
\hline $\mathrm{CO}(\mathrm{ppb})$ & Darus Salam & 3.6 & 2.9 & 1.3 & 2.1 & 2.4 \\
\hline \multirow[t]{2}{*}{ NAAQS-9 } & Narayonganj & 1.4 & 0.6 & 0.4 & 1.0 & 0.8 \\
\hline & Gazipur & 2.1 & 1.3 & 1.1 & 1.1 & 1.4 \\
\hline $\mathrm{O}_{3}(\mathrm{ppb})$ & Darus Salam & 9.7 & 9.7 & 12.6 & 3.8 & 9.2 \\
\hline \multirow[t]{2}{*}{ NAAQS-80 } & Narayonganj & 4.8 & 7.5 & 4.7 & 5.6 & 5.5 \\
\hline & Gazipur & 6.3 & 7.1 & 6.7 & 9.6 & 7.1 \\
\hline
\end{tabular}

Winter- November to January, Summer- February to April, Rainy (Wet)- May to October

AS shown in Table-4, there is a seasonal variation, with daily mean concentrations of $\mathrm{PM}_{2.5}$ being higher than Bangladesh NAAQS limit in all the areas in winter. $\mathrm{PM}_{10}$ was found higher than the NAAQS limit in all the areas in winter, pre-monsoon, and post-monsoon. However, $\mathrm{PM}_{10}$ was elevated in monsoon only in Narayangonj. None of the gaseous pollutants were found to be above NAAQS limits in any season. In Dhaka, the average concentration of $\mathrm{PM}_{2,5}$ from 2016 to 2020 was $86.1 \mu \mathrm{g} / \mathrm{m}^{3}$ (William, 2020): $37.7 \mu \mathrm{g} / \mathrm{m}^{3}$, in September $2019,64.6 \mu \mathrm{g} / \mathrm{m}^{3}$ in October and $181.8 \mu \mathrm{g} / \mathrm{m}^{3}$ in January 2020 with an annual average concentration of $83.3 \mu \mathrm{g} / \mathrm{m}^{3}$ (IQAir, 2020c).

\section{Household Air Pollution}

\subsection{Household air pollution has been recognized as a serious problem with significant health impacts in Bangladesh}

Biomass fuel emissions from cookstoves are responsible for $41 \%$ of the household pollutants (Nahar et al., 2016; Weaver et al., 2019; Salje et al., 2014). A 2020 study showed that $85.5 \%$ of the respondents used biomass fuel. The average cooking years of the respondents were $26.9 \pm 8.59$ years, and the daily average cooking duration was 3.09 hours (Ahmad et al., 2020). The total biomass fuel consumption is 44 million tons annually (MoPEMR, 2013). Commonly used biomass fuels are wood (41\%), leaves, bamboo, cow dung, straw, paddy husk, jute sticks, bagasse, and sawdust (Mamun et al., 2009). Rural households usually use traditional stoves, and one family can consume 7 to $8 \mathrm{~kg}$ biomass fuel per day (MoPEMR, 2013). However, the efficiency of traditional stoves is poor, and only about 5-15\% of available fuel energy is utilized (Mamun et al., 2009; Khandker et al., 2015). Moreover, due to incomplete combustion, these traditional stoves emit heavy smoke and many harmful pollutants such as PMs, carbon monoxide, sulfur dioxide, nitrous oxides, as well as formaldehyde and other carcinogens (Weaver et al. 2019). Culturally, a Bangladeshi woman prepares food for the family and spends 3-7 hours cooking. Thus, women and young children are heavily exposed (WHO, 2006).

About 30 million households in Bangladesh use biomass fuel (Mamun, 2009; MoPEMR, 2013). This includes $90 \%$ of households of rural areas, about 24 million households (Mamun et al. 2009). After standardization of collected information, it was found that in 2019 the proportion of the population with primary reliance on clean fuels and technologies for cooking was $23 \%$, while it was $13.6 \%$ in 2011 . Similarly, the number of people with primary reliance on clean fuels and technologies for cooking was 38.739 million in 2019 and 20.932 million in 2011 (GHO, 2021). In Bangladesh, the number of solid fuel users has decreased to 6.5 million population from 2010 to 2019 (SOGA, 2019). In addition, Bangladesh Improved Cook Stoves Program has installed 1.7 million Improved Cook Stoves since its inception in 2013, reducing greenhouse gas emissions (Ahmed, 2019). Department of Health Survey revealed that 50\% of urban households in Bangladesh use solid fuel. Considering that Bangladesh's urban population is about 55 million and the average household size is 5 , about 5.5 million urban households use solid fuels for cooking purposes (NIPORT, 2016). 
Linear regression analysis of emitted PM2.5 and CO concentrations from biomass stove showed a decreasing trend of geometric mean to neighbor homes sharing a wall with the indexed home than neighbor homes that do not share a wall with indexed home. Thus, exposure is a risk if a neighboring house uses biomass fuel for cooking purposes (Weaver et al., 2019; Salje et al., 2014). In addition, the concentration of dust particles, VOC, e.g., benzene, toluene, xylene, and $\mathrm{CO}$ and $\mathrm{CO} 2$ were significantly higher in biomass fuel users $(\mathrm{P}<0.05)$ than fossil fuel user kitchens. Other factors contributing to indoor air pollutants are tobacco smoke, poor ventilation, dust, building materials, carpets, pesticides, mosquito coils, chemicals, and diesel generators (Nahar et al., 2016; Dasgupta et al., 2009).

\subsection{Diesel Generator}

Diesel generators (DG) are used in almost $100 \%$ of high-rise buildings of Dhaka city. If they are used for several hours, the concentrations of PM 2.5 and $\mathrm{PM}_{10}$ increased by $50-100 \%$, and in households using DG for more than eight hours, the PM levels remained high throughout the day. The average levels of $\mathrm{PM}_{2.5}$ and $\mathrm{PM}_{10}$ were $130 \mu \mathrm{g} / \mathrm{m}^{3}$ and $300 \mu \mathrm{g} / \mathrm{m}^{3}$, respectively, and maximum levels reached $300 \mu \mathrm{g} / \mathrm{m}^{3}$ and $1900 \mu \mathrm{g} / \mathrm{m}^{3}$, respectively (Jha, 2018).

\section{Health Impact Of Air Pollution In Bangladesh}

\subsection{Morbidity}

Both short and long-term exposure to high levels of air pollution increases the risk of respiratory infection, heart diseases, and lung cancer. Children, the elderly, the already ill, and poor people are more susceptible (WHO, 2019). Long time exposure to ambient particulate matter accounts for $62 \%$ of all pollution-attributable deaths and 55\% Disability Adjusted Life Years (DALYs) (SOGA, 2020b).

Ambient air pollution was the cause of 736 Years of Life Lost (YLL) and 816 Disability Adjusted Life Year (DALY) per 100,000 population in Bangladesh in 2012 (WHO, 2016), and the Disability Adjusted Life Year (DALY) due to air pollution was 2608 per 100,000 population in 2016 in Bangladesh (WHO, 2021). WHO rapid scenario analysis report stated that $80 \%$ of the PM2.5 related deaths could be avoided, and the countries with a higher concentration of PM2.5 will be benefited the most in reducing the burden of disease; if air pollution could be reduced according to WHO guideline values (WHO, 2021 ), i.e., 10 $\mu \mathrm{g} / \mathrm{m} 3$.

\subsubsection{Mortality}

According to WHO, 13.7 million deaths occur globally each year due to environmental risk factors, with household air pollution and ambient air pollution contributing 3.8 million and 4.2 million deaths, respectively (GHO, 2018a). Ambient air pollution caused 37,449 deaths in Bangladesh in 2012 (WHO, 2016). Total death attributable to ambient air pollution in Bangladesh was 82,398 in 2016 (GHO, 2018b). Disease-specific analysis reveals that Lower Respiratory Tract Infection (LRTI), Chronic Obstructive Pulmonary Diseases (COPD), Lung Cancer, Ischemic Heart Disease (IHD), and stroke were the cause of 3850, $8316,4375,10291$, and 10617deaths respectively in 2012 (WHO, 2016). WHO further reported that in 2012 crude death rate due to ambient air pollution was 24 per 100,000 population. In 2016 the crude death rate was 103.4 due to air pollution (ambient and household), while in the case of household air pollution, it was 69.47 per 100,000 population (WHO, 2021). This indicates an increase in the death rate due to ambient air pollution from 24 in 2012 to 34 per 100,000 in 2016. Air pollution causes the third-highest risk for premature death in the South East Asian region, including Bangladesh (World Bank, 2021). Another report stated that in Bangladesh, 123,000 deaths were related to household and ambient air pollution in 2017 and 173,500 in 2019 (AQLI, 2021). Five diseases, namely lung cancer $13 \%$, lower respiratory tract infection $7 \%$, chronic obstructive pulmonary diseases $7 \%$, Ischemic heart disease $6 \%$, and stroke $5 \%$ are attributable to air pollution among the top 10 diseases of death in Bangladesh (SOGA, 2019). Eco-Social Development Organization (ESDO), an action-research conservation NGO in Bangladesh, reported (https://esdo.org/resource-center/publication/annual-reports/) in 2019, at least 200,000 people in Bangladesh might have died because of long term exposure to polluted air (ESDO, 2020).

\subsubsection{Respiratory disease:}

The ESDO reported that asthmatic patients rose from 3,326 in 2015 to 78,806 in 2019. The ESDO report did not analyze the contribution of air pollution on increased asthmatic morbidity in Bangladesh but stated that air pollution may have contributed to the increase (ESDO, 2020). There is an association between prenatal exposure to air pollutants and adverse birth outcomes, e.g., preterm birth, lower birth weight, and developmental lung defects, further associated with respiratory diseases and reduced lung function in children and adults (Kim et al., 2018). Air pollution may damage lung development in children and adolescents and is one of the main factors for allergic respiratory diseases (González-Díaz et al., 2016). The health effects of air pollution depend on the components and sources of pollutants, which vary with countries, season, and time. Particularly air pollution can induce the acute exacerbation of COPD and increase respiratory morbidity and Mortality (Jiang et al., 2016).

\subsection{Health impacts of household air pollution in Bangladesh}

In Bangladesh, 8,656 deaths and 791,065 DALYs were caused due to Lower Respiratory Tract Infection, attributable to household air pollution in children under 5 in 2010 (WHO, 2016). In 2019 the total number of deaths in Bangladesh due to indoor air pollution was 74,000 (SOGA, 2020a). A community-based study in Bangladesh revealed that improved cooking stoves reduce respiratory infection among children in a rural area, and $46.5 \%$ and $69.0 \%$ of the exposed women and children respectively who used Traditional Cooking Stoves (TCS) suffered more from respiratory illnesses than the users of ICS (Khandker et al. 2015; Khandker et al. 2014). Another community-based study revealed that women who used biomass fuel suffered significantly more (22.1\%) from COPD than those who used non-biomass fuel (8.2\%) for cooking purposes (Nahar et al. 2016). 
In Bangladesh, the number of solid fuel users has decreased to 6.5 million population from 2010 to 2019 (SOGA, 2019). Bangladesh Improved Cook Stoves Program has installed 1.7 million Improved Cook Stoves since its inception in 2013 that have contributed to reducing greenhouse gas emissions (Ahmed, 2019). It might have an impact on reducing the total number of 26,100 deaths due to household air pollution. However, from 2010 to 2019 , the total number of deaths attributable to PM2.5 pollution increased (SOGA, 2020b). The concentration of PM2.5 in the air of Bangladesh has increased from 56.03 in 2010 to 62.79 in 2016 (GHO, 2021), which might have contributed to an increased number of total deaths due to PM2.5 pollution. An urban-based survey in Bangladesh revealed that $40 \%$ of Bangladeshi households exclusively use biomass fuel, and $54 \%$ use indoor kitchens. The prevalence of respiratory symptoms in under-five children was higher among in-house biomass fuel users. Multiple logistics regression analysis showed that respiratory symptoms among under-five children were increased among in-house biomass fuel users compared with non-biomass users, and the risk of respiratory symptoms was significantly associated with mother's birth complications (Hasan et al. 2019). Among 5934 study households, 5150 ( $87 \%$ ) households used solid fuels in 2011, which reduced to 4864 solid fuel user households (85\%) in 2014. This study reveals that prenatal exposure to ambient PM 2.5 was associated with stunting in boys but not girls, and postnatal exposure was associated with stunting in both genders (Kurata et al. 2020).

\subsection{Economic Implications due to Air Pollution in Bangladesh}

The Organization for Economic Co-operation and Development (OECD) reported that the market impact on labor productivity, health expenditures, and agricultural crop yield loss attributable to outdoor air pollution are projected to increase by 1\% global GDP cost by 2060 (OECD, 2016). Expanding economic activity and energy demand will lead to significantly increased emissions of air pollutants and considerable effects on the economy in the absence of strict policy to limit air pollution. The OEDC report estimated that air pollution will increase healthcare costs from US\$ 21 billion in 2015 to US\$ 176 billion in 2060, and the productivity loss due to workers' sickness or absence is projected to increase from 1.2 billion (currently) to 3.7 billion (OECD, 2018). Every year losses in Bangladesh due to environmental degradation and pollution amount to about US \$ 6.5 billion (World Bank, 2018). Air pollution reduces the productivity of healthy workers, including in the Ready-Made Garment (RMG) industry, which is significant for continued competitiveness and high GDP growth in Bangladesh. The annual productivity loss of health workers in the RMG industry caused by ambient air pollution is estimated at US \$90 million annually. The treatment and time costs of illness attributed to air pollution are estimated at US \$130 million (World Bank, 2018).

\section{Role Of Government In Combating Ambient Air Pollution In Bangladesh}

\section{1 Bangladesh government policies}

Bangladesh's government has prioritized air pollution strategies and undertaken sector-specific policies and rules. The Environment Conservation Act (ECA) 1995, The Environment Conservation Rules 1977, The Environment Pollution Control Ordinance 1977, Bangladesh Environment Court Act 2000, and other Acts relevant to Environment have been updated to impose intense penalties on polluters and industries (Bangladesh Environmental Protection act, Bangladesh Environmental Conservation Act, Bangladesh Environmental Court Act, Bangladesh Environment Pollution Act, Bangladesh Motor Vehicle Ordinance 1983). Bangladesh government has planned to reduce urban PM2.5 concentration from $78 \mu \mathrm{gm} / \mathrm{m} 3$ level in 2013 to $73 \mu \mathrm{gm} / \mathrm{m} 3$ in $2020 \mathrm{under}$ its seventh five-year plan. To achieve this goal government has implemented the clean air program, cleaner fuel and transport standards, and strict enforcement of the Brick Kiln Act 2013.

\section{Brick Kilns}

The Brick Manufacturing and Kiln Construction (Control) Act 2013 converted traditional brick kilns into more energy-efficient kilns to reduce air pollution, especially PM, in urban air (DOE, 2019a) methods in brick manufacturing industries. Replacing Fixed Chimney Kilns (FCK) with Improved Zigzag Kilns (IZKs) burn less coal and emit less PM, and water scrubber systems can absorb PM to reduce emissions. This intervention is supported by funding and technical support by the infrastructure Development Company Limited (IDCOL), the DOE, WB, Asian Development Bank (ADB), and other donor agencies. This also supports projects in household energy, rural electrification, biogas, and solar energy (ESMAP, 2019a).

\section{Motor vehicles and fuels}

The Government of Bangladesh promulgated motor vehicle ordinance 2011 for vehicle emissions standards. Vehicles are tested at roadside checkpoints to control vehicular emissions. (DOE, 2012). In addition, the government banned the import of vehicles older than five years and reduced import duties on newer vehicles. The vehicle emissions standard of 1977 was strengthened in 2005 and reinforced in 2014 to correspond to Euro 3.

In terms of fuels, the Chittagong oil refinery was upgraded to lower the sulfur content in the oil below 500 ppm. To reduce the sulfur concentration in the air (DOE, 2019b), compressed natural gas (CNG) was introduced to replace gasoline, which improved the ambient air in Dhaka. In July 1999, the government banned leaded gasoline, and in 2003 , forbidding two-stroke three-wheeled baby taxis that had used leaded fuel.

\section{Industry}

For Environmental Clearance purposes, industries/projects are categorized into four classes: Green, Amber-A, Amber-B, and Red. The government has exempted 5\% VAT and five-year income tax on equipment and spare parts of renewable energy projects, including energy audits. Bangladesh Bank (the central bank) launched the Bangladeshi Taka (BDT) 2 billion green banking refinance scheme in August 2009; to help reduce industrial pollution and increase power supply (UNEPA, 2015). As a result, there is an increasing trend in green finance in Bangladesh (Rana and Siddique, 2019). The Bangladesh Government has contributed 7\% of public expenditure for green growth activities (Macgregor et al. 2016). In addition, the government introduced a 1\% 'green tax' as an environment protection surcharge for the budget 2014-2015 fiscal year and adopted the renewable energy policy of Bangladesh 2008 (Bhuiyan et al. 2020). 


\section{Clean Cookstoves}

Bangladesh Improved Cook Stoves Program has installed 1.7 million Improved Cook Stoves. Bangladesh Environment and Development Society (BEDS) provides technical and financial support to the people of a selected coastal village in Bangladesh. It has supplied the villagers with fuel-efficient cooking stoves, solar lamps, solar panels, solar homes, and solar generators (BEDS, 2020).

\subsection{International and national NGOs/Institute's role}

Among the 40 most polluted cities of the world, 37 are situated in Southeast Asia. Air pollution causes the third-highest risk for premature death in the South East Asian region, including Bangladesh (World Bank, 2021). The economic impact due to air pollution (ambient and household) is estimated at US\$ 3.69 billion in urban Bangladesh and US\$ 0.81billion in Dhaka alone, which are 1.89 percent and 0.41 percent of the 2015 national GDP, respectively (World Bank, 2018). South Asia is the epicenter of ambient air pollution, with air pollution being transported across borders and spreading to places far away from the source. The World Bank declared the vision "South Asia Clean Air 2030" and urged a coordinated effort at regional, national, and local levels to address this problem (World Bank, 2021).

The Department for International Development (DFID) of the United Kingdom has carried out an intensive study to identify knowledge and policy gaps around air pollution in South Asia, including Bangladesh. This report states that the use of fiscal measures requires excellent monitoring, enforcement capacity, and good governance. A strategy to take two-stroke engine vehicles and old vehicles off the roads is progress. The Air Pollution Reduction Strategy highlights several capacity constraints for controlling air pollution, including insufficient monitoring, laboratory, inventory compilation, health impact assessment, and stove certification resources. Pollution reduction strategies in Bangladesh are based on qualitative multi-criteria evaluation because of the lack of quantitative benefit-cost modeling (Sharma et al., 2019).

The World Bank has been providing technical and financial support to the Bangladesh government to develop legislation and strategies on air pollution control measurements, e.g., implementation of CASE project and create a draft "Clean Air Act-2019" (World Bank, 2019). In addition, the German International Cooperation (GIZ) is working with the Bangladesh government through energy-efficient technology that helps reduce fossil fuel use, indoor air pollution, and greenhouse gas emissions (GIZ, 2021).

\section{Role Of Government In Combating Household Air Pollution In Bangladesh}

\subsection{In Bangladesh}

About 6.5 million population has stopped solid fuel use in the kitchen from 2010 to 2019 due to increased awareness of the health risks of indoor air pollution (SOGA, 2020b). WHO-Environmental Health Unit (WHO-EHU) of Bangladesh carried out several pilot studies collaborating with the Directorate General of Health Services (DGHS). WHO-EHU has also developed a training manual on the health effects of indoor air pollution and trained communitybased health workers to share the message within their respective working areas. The community health workers advise the mothers to keep the children away from the kitchen during the cooking time and involve family members to prepare food by rotation. An unpublished report reveals that respiratory tract infection among children was reduced during the post-training period. The Director Non-Communicable Diseases of the DGHS is training health workers to a limited extent; however, extensive work on awareness-raising of health workers is required to achieve the government's target for reducing ambient air pollution exposure. The Bangladesh Country Action Plan for Clean Cookstove aims to achieve a $100 \%$ clean cooking solution by 2030 with a comprehensive intervention plan involving potential donors, entrepreneurs, NGOs, and policymakers (MoPEMR, 2013).

\subsection{Use of Improved Cooking Stove (ICS)}

Improved Cook Stoves are cooking devices designed to improve combustion and the efficiency of biomass. They consume less fuel, reduce cooking time and emission and increase convenience. A local ICS was developed by the Bangladesh Council of Scientific and Industrial Research (BCSIR) in 2005. In May 2013, the Honorable Prime Minister of Bangladesh inaugurated the ICS program, and the World Bank is providing necessary financial support for the implementation of the program. The Research and Development section of (IDCOL) upgraded the stove and has increased the thermal efficiency above $35 \%$ https://idcol.org/home/ics. German International Cooperation (GIZ) and DoE started promotional activities for ICS to increase ICS use. This stove is connected with a chimney to bring smoke out of the kitchen to reduce exposure to the pollutants. The proper and regular use of this ICS reduces fuel consumption by $50 \%$ (Shankar et al., 2014). In addition, it reduces the smoke emission the concentrations of $\mathrm{CO}_{\text {and }} \mathrm{PM}_{2.5}$ by $23 \%$ and $59 \%$, respectively, compared to traditional Stoves (MoPEMR, 2013) and thus decreases the adverse health effects.

The Infrastructure Development Company Limited (IDCOL) has disseminated 2.67 million Improved Cooking Stoves (ICS) as of July 2021 and has set a target of sharing a total of 5 million ICS by June 2023. https://idcol.org/home/ics. The Energy Sector Management Assistance Program (ESMAP) is helping the Bangladesh government embed and scale-up cooking programs by developing a supply chain, focusing on consumer behavior, innovative marketbased strategies, and efficient stove technologies (ESMAP, 2019b). Furthermore, the German International Cooperation (GIZ) is supporting the Bangladesh government to implement Improved Cooking Stoves (ICS), Retained Heat Cooker (RHC), Promotion of technology, and improving energy efficiency (GIZ, 2021). In addition, the Green Climate Fund (GCF) and World Bank signed an agreement to expand the market for improved cooking stoves in Bangladesh. This project will help reduce greenhouse gas emissions and deforestation and lessen health risks for the Bangladeshi population. An estimated 30,324,800 people will benefit from this project, and it will reduce emissions by 254 940, 000 tCO2 equivalent (IDCOL, 2019).

\section{Conclusion}


In 2020, Dhaka was the 2nd most polluted city, and Bangladesh became the world's top polluted country. The government has implemented, and updated regulations formulated policies and strategic plans, and undertook several sector-specific programs and activities to control air pollution. The data generated by the CAMS are used to define the nature and severity of pollution in the cities, identify pollution trends in the country, and develop air models and support the Air Quality Index for public information. The government has exempted tax on equipment and spare parts of renewable energy projects. Programs include energy audit, distribution of improved cookstoves, improved rice parboiling. Bangladesh Bank (the central bank) launched the Bangladeshi Taka (BDT) 2 billion green banking refinance scheme in August 2009 to help reduce industrial pollution and increase power supply.

\section{Declarations}

\section{Ethical Approval}

The Research Ethics Committee (REC) of the Faculty of Allied Health Sciences (FAHS) in Daffodil International University (DIU), Dhaka, Bangladesh, has reviewed approved this study.

\section{Consent to Publish}

Permission to publish the content of this article has been granted by the concerned personnel.

\section{Authors Contributions}

SK designed, conceptualized the study, acquired the data, and drafted the article; ASMM checked the manuscript and ensured the quality of the data and procedures; SAA, AM, \& AA critically edited and revised the paper. All authors have read and approved the final version of the article.

\section{Funding}

The authors report no funding source.

\section{Competing Interests}

All authors declare that they have no competing interests.

\section{Availability of data and materials}

The data and materials are available on request.

\section{References}

1. Ahmad SA, Faruquee MH, Yasmin R, Sultana S, Chowdhury S (2020) Chronic obstructive pulmonary disease among the users of improved cooking stoves and traditional cooking stoves. Bangladesh Medical Res Counc Bull 46:00-00

2. Ahmed J (2019) Bangladesh offers a successful clean cooking program model: IMPACT Issue 17. Available from: https://documents1.worldbank.org/curated/en/571731573763114047/pdf/Bangladesh-Offers-Model-of-Successful-Clean-Cooking-Program.pdf (Accessed on 29.08.2021)

3. AQLI (2021) The death toll from air pollution sees an alarming rise in Bangladesh. https://aqli.epic.uchicago.edu/news/death-toll-from-air-pollutionsees-alarming-rise-in-bangladesh/ (Accessed on 08.09.2021)

4. Arnab IZ, Ali T, Shidujaman M, Hossain MM (2013) Consideration of Environmental Effect of Power Generation: Bangladesh Perspective: Energy and Power Engineering. 5:1521-1525. 10.4236/epe.2013.54B288

5. BEDS (2020) Echo Village Project in Bangladesh, 2015-2020. Available from: https://www.bedsbd.org/projects/ongoing-projects/1 (Accessed on 17.10.2021)

6. Begum BA, Biswas SK, Nasiruddin M (2010) Trends and spatial distribution of air particulate matter in Dhaka city. J Bangladesh Academy of Sci 34(1):33-48

7. Begum BA, Hopke PK (2018) Ambient Air Quality in Dhaka Bangladesh over Two Decades: Impacts of Policy on Air Quality. Aerosol Air Qual Res 18:1910-1920. https://doi.org/10.4209/aaqr.2017.11.0465

8. Bhuiyan MAH, Hassan S, Darda MA, Habib MW, Hossain MB (2020) Government Initiatives for Green Development in Bangladesh. Preprints; 2020080298. DOI: 10.20944/preprints202008.0298.v1

9. Bonasoni P, Cristofanelli P, Marinoni A, ElisaVuillermoz, Adhikary B (2010) Atmospheric brown clouds in the Himalayas: First two years of continuous observations at the Nepal Climate Observatory-Pyramid (5079 m). Atmos Chem Phys 1:7515-7531

10. CASE ( (2018) ). Ambient Air Quality in Bangladesh. Clean Air and Sustainable Environment Project. Department of Environment 2018, Agargaon, Dhaka. Available from: http://case.doe.gov.bd/index.php?option=com_content\&view=article\&id=5\&ltemid=9 (accessed on 07.09.2021)

11. Dasgupta S, Wheeler D, Huq M, Khaliquzzaman M (2009) Improving indoor air quality for poor families: a controlled experiment in Bangladesh. Indoor Air 19(1):22-32 
12. DOE ( (2012) ). Government of the People's Republic of Bangladesh. Revisions of vehicular emission standards for Bangladesh. Available from: http://case.doe.gov.bd/file_zone/reports_publications/standards/Revisions\%20of\%20Vehicular\%20Emission\%20Standards\%20for\%20Bangladesh.pdf (Accessed on 30.07.2021)

13. DOE ( (2019a) ). Sources of Air pollution in Bangladesh. Brick kiln \& Vehicle emission Scenario. Department of Environment. Agargaon, Dhaka. Available from: http://doe.portal.gov.bd/sites/default/files/files/doe.portal.gov.bd/page/cdbe516f_1756_426f_af6b_3ae9f35a78a4/2020-06-10-10-145c997af8b7845a59a5f8dd1c41dd7f13.pdf (Accessed on 20.07.2021)

14. DOE ( (2019b) ). Air Pollution Reduction Strategy for Bangladesh, Final Report, 2012. Department of Environment. Available from: https://www.semanticscholar.org/paper/Air-Pollution-Reduction-Strategy-for-Bangladesh/a162734badbb64d530d55708226e4eacb4d12a39 (Accessed on 20.04.2021)

15. ESDO (2020) study report. Available from: https://esdo.org/dhaka-4th-polluted-city-globally-2/ (Accessed on 01.07.2021)

16. ESMAP (2019a) Bangladesh offers Successful Model of Clean Cooking Program: The Energy Sector Management Assistance Program (ESMAP): The World Bank: Issue -17. Available from: https://documents1.worldbank.org/curated/en/571731573763114047/pdf/Bangladesh-Offers-Model-ofSuccessful-Clean-Cooking-Program.pdf (Accessed on 01.07.2021)

17. ESMAP (2019b) Updated Environmental and Social Management Framework-2014: Governments of the People's Republic of Bangladesh. Available from: https://annualreport.esmap.org/ (Accessed 05.07.2021)

18. GIZ (2021) Bangladesh: Renewable Energy and Energy Efficient Program (REEEP)-2021. https://www.giz.de/en/downloads/giz2017-en-reneableenergy-bangladesh.pdf (Accessed on 01.07.2021)

19. Global Health Observatory (GHO) (2018a) Public Health and Environment Available from: https://www.who.int/data/gho/data/themes/public-healthand-environment (Accessed on 29.08.2021)

20. Global Health Observatory Data (GHO) (2018b) Available from: https://apps.who.int/gho/data/node.main.BODAMBIENTAIRDTHS?lang=en (Accessed on 29.08.2021)

21. Global Health Observatory Data (GHO) (2021) : Clean fuels and technologies by country. Available from: https://apps.who.int/gho/data/node.main.HHAIRFUELSCLEAN?lang=en (Accessed on 29.08.2021)

22. Gonzalez-Diaz SN, Ariaz-Cruz A, Macouzet Sanchez C, Partida-Ortega AB (2016) Impact of air pollution on respiratory allergic diseases. DOI: 10.1016/j.rmu.2016.10.006. Available from: https://www.elsevier.es/en-revista-medicina-universitaria-304-articulo-impact-air-pollution-in-respiratoryS166557961730011X

23. Hasan M, Tasfina S, Haque SMR et al (2019) Association of biomass fuel smoke with respiratory symptoms among children under 5 years of age in urban areas: results from Bangladesh Urban Health Survey, 2013. Environ Health Prev Med 24:65. https://doi.org/10.1186/s12199-019-0827-3

24. IDCOL (2017) Study of indoor air pollution levels in households with improved and traditional cooking stoves: Available from: https://idcol.org/download/Indoor_Air_Pollution_(IAP)_study_conducted_by_Bangladesh_Atomic_Energy_Commission_(BAEC).pdf (Accessed on 07.09.2021)

25. IDCOL (2019) Green Climate Fund and World Bank partner to boost the cookstove market in Bangladesh: Available from: https://www.greenclimate.fund/news/gcf-and-world-bank-partner-boost-cookstove-market-bangladesh (Accessed on 29.08.2021)

26. IQAir (2020c) Air quality in Dhaka, Air quality index (AQI), and $\mathrm{PM}_{2.5}$ air pollution in Dhaka. Available from: https://www.iqair.com/bangladesh/dhaka (Accessed on 20.07.2021)

27. IQAir ( (2020a) ). Air quality in Dhaka. Air quality index (AQI) and PM2.5 air pollution in Dhaka. Available from: https://www.iqair.com/bangladesh/dhaka (Access 20.07.2021)

28. IQAir (2020b) The 2020 World Air Quality Report. Available from: https://www.iqair.com/world-most-polluted-cities/world-air-quality-report-2020-en.pdf (Accessed on 07.07.21)

29. Jha D (2018) 0. (CSE. Areas with diesel generators more polluted: Study. Available from: https://www.hindustantimes.com/gurugram/areas-withdiesel-generators-more-polluted-study/story-4xnqBb1nDtC7y5tFxNQYzM.html (accessed 07.09.2021)

30. Jiang XQ, Mei XD, Feng D (2016) Air pollution and chronic airway diseases: what should people know and do? J Thorac Dis 8(1):E31-E40. doi:10.3978/j.issn.2072-1439.2015.11.50

31. Khandker S, Ahmad SA, Ahmed R, Mollah AR, Parvez F, Khan MH (2015) Comparison of Respiratory problems among Women and Children of Rural Households using Improved Cook Stove and Traditional Cook Stove. JOPSOM; 34:8-13

32. Khandker S, Ahmed R, Faruquee K (2014) Health effect of Biomass Fuel Combustion on Women and Children and Intervention of Improved Cook Stove and Hand Washing Practices (Phase I), vol 1. Journal of Allied Health Sciences, Daffodil International University, 2

33. Kim D, Chen Z, Zhou LF, Huang SX (2018) Air pollutants and early origins of respiratory diseases. Chronic Dis Transl Med 4(2):75-94 Published 2018 Jun 7. doi:10.1016/j.cdtm.2018.03.003

34. Kurata M, Takahashi K, Hibiki A (2020) Gender differences in associations of household and ambient air pollution with child health: Evidence from household and satellite-based data in Bangladesh. World Dev 128:104779. https://doi.org/10.1016/j.worlddev.2019.104779

35. Kurata Masamitsu K, Takahashi A, Hibiki (2020) Gender differences in the association of household and ambient air pollution with child health: Evidence from households and satellite-based data in Bangladesh. World Dev 128:104779. https://www.sciencedirect.com/science/article/pii/S0305750X19304280 Accessed on 25.07.2021) 
36. Macgregor J, Firoz R, Uddin N, Islam M, Sattar MA (2016) Green Growth Diagnostic-Bangladesh. Working paper economic dialogue on the green, Amad Smith International, UK AID. Available from: https://www.greengrowthknowledge.org/research/green-growth-diagnostic-bangladesh (Accessed on 17.10.2021)

37. Mamun MRA, Kabir MS, Alam MM, Islam DMM (2009) Utilization Pattern of Biomass for Rural Energy Supply in Bangladesh. Int J Sustain Crop Prod 4:62-71

38. MoPEMR (2013) Country Action Plan for Clean Cookstoves. Power Division, Ministry of Power, Energy and Mineral Resources Ministry of Power, Energy and Mineral Resources, GOB. Available from: https://policy.asiapacificenergy.org/node/219 (Accessed on 25.07.2021)

39. Nahar M, Khan MH, Ahmad SA (2016) Indoor Air Pollutants and Respiratory Problems among Dhaka City Dwellers. Arch Com Med Public Health 2(1):032-036. DOI:10.17352/2455-5479.000014

40. Nahar N, Mahiuddin S, Hossain Z (2021) The Severity of Environmental Pollution in the Developing Countries and Its Remedial Measures. Earth 2:124139. https://doi.org/ 10.3390/earth2010008

41. NIPORT (National Institute of Population Research and Training (2016)Mitra and Associates, and ICF International.

42. OECD (2016) The economic consequences of outdoor air pollution. Available from: https://www.oecd.org/env/the-economic-consequences-of-outdoorair-pollution-9789264257474-en.htm (Accessed on 31.08.2021)

43. OECD (2018) Policy highlights: The economic consequences of outdoor air pollution. Available from: https://www.oecd.org/environment/indicatorsmodelling-outlooks/Policy-Highlights-Economic-consequences-of-outdoor-air-pollution-web.pdf (Accessed on 01.09.2021)

44. Rahman M (2021) Bangladesh transitioning to a developing country. Available from: https://cpd.org.bd/bangladesh-transitioning-to-developingcountry/ (Accessed on 26.08.2021)

45. Rahman MM, Mahamud S, Thurston GD (2019) Recent spatial gradients and time trends in Dhaka, Bangladesh, air pollution and their human health Implications. J Air \& Waste Management Association. 2019; 69:4, 478-501, DOI: 10.1080/10962247.2018.1548388

46. Rahman SM (2021) Air quality assessment and the health effects of air pollution in Dhaka City through impact-pathway mode. Available at: http://lib.buet.ac.bd:8080/xmlui/handle/123456789/479 (Accessed on 07.09.2021)

47. Rana M, Mahmud M, Khan SMHK, Sivertsen B (2016) Investigating Incursion of Transboundary Pollution into the Atmosphere of Dhaka, Bangladesh: Advances in Meteorology 2016:1-11. 10.1155/2016/8318453

48. Rana M, Siddique MAB (2019) Green Banking in Bangladesh: A Descriptive Analysis. IOSR J of Bus and Manage 21(7):57-67

49. Research \& Publication-UD (2021) Department of Soil, Water and Environment, University of Dhaka. Available from: https://du.ac.bd/researchDetails/165 (Accessed on 07.09.2021)

50. Sakib SN (2021) World Environment. Bangladesh_ Air pollution engulfs lives, From Environment. Available from: https://www.aa.com.tr/en/environment/bangladesh-air-pollution-engulfs-lives-environment/2190506 (accessed on 20.07.2021)

51. Salje H, Gurley ES, Homaira N, Ram Pk, Haque R, Petri W et al (2014) impact of neighborhood biomass cooking patterns on episodic high indoor particulate matter concentrations in clean fuel homes in Dhaka, Bangladesh. Indoor Air 24(2):213-220

52. Shankar A, Johnson M, Kay E, Pannu R, Beltramo T, Derby E, Harrell S, Davis C, Petach H (2021) Maximizing the benefits of improved cookstoves: moving from acquisition to correct and consistent use. Glob Health SciPract. 2014 Aug; 2(3): 268-274

53. Sharma S, Khanna I, Ghosh P (2019) 0. Scoping Study for South Asia Air Pollution. Available from: https://www.gov.uk/research-for-developmentoutputs/scoping-study-for-south-asia-air-pollution (Accessed on 10.01.2021)

54. Singh RP, Kaskaoutis DG (2014) Crop Residue Burning: A Threat to South Asian Air Quality. Available from: https://eos.org/features/crop-residueburning-threat-south-asian-air-quality (Accessed on March 2021)

55. South Asia Co-operative Environment Programme (SACEP) (1998) Climate Change. Available from: http://www.sacep.org/programmes/maledeclaration (Accessed 2507.2021)

56. The States of Global Air (SOGA) (2020a) Air pollution increases the risk of serious health problems for newborns https://www.stateofglobalair.org/health/newborns (access 20.07.2021)

57. The States of Global Air (SOGA) (2020b) Trends in ambient PM. Available from: https://fundacionio.com/wp-content/uploads/2020/10/soga-2020report.pdf (accessed 20.07.2021)

58. The States of Global Air-2019 (SOGA). Bangladesh. Available from: https://www.stateofglobalair.org/sites/default/files/soga_2019_bangladesh.pdf (Accessed on 22.07.2021)

59. UNEPA: Air Quality Policy of Bangladesh (2021) : The table is prepared based on research that UNEP conducted in 2015, in response to Resolution 7 of the UNEPA 1 https://wedocs.unep.org/bitstream/handle/20.500.11822/17093/Bangladesh.pdf?isAllowed=y \&sequence=1 (Accessed on 06.07.

60. Weaver AM, Gurley ES, Crabtree-Ide C et al (2019) Air pollution dispersion from biomass stoves to neighboring homes in Mirpur, Dhaka, Bangladesh. BMC Public Health 19:425. https://doi.org/10.1186/s12889-019-6751-z

61. William A (2020) Where Does Bangladesh and Dhaka's Air Pollution come from? Smart Air. Available from: https://smartairfilters.com/en/blog/bangladesh-dhaka-air-pollution-sources (Accessed on 20.07.2021)

62. World Health Organization (WHO) (2018a) Ambient Air Pollution. Available from: https://www.who.int/teams/environment-climate-change-andhealth/air-quality-and-health/ambient-air-pollution/pollutants (Accessed on 29.08.2021)

63. World Bank (2018) "Enhancing Opportunities for Clean and Resilient Growth in Urban Bangladesh: Country Environmental Analysis. The World Bank Group. Available from: https://documents1.worldbank.org/curated/en/585301536851966118/pdf/129915-CEA-P161076-PUBLIC-Disclosed-9-16-

Page $12 / 14$ 
2018.pdf (Accessed on 22.07.2021)

64. World Bank (2019) Draft Clean Air Act. Available from: https://www.google.com/search?q=Clean+air+act-

2019+bangladesh\%2C+World+Bank\&oq=Clean+air+act019+bangladesh\%2C+World+Bank\&aqs=chrome..69i57.21841j0j7\&sourceid=chrome\&ie=UTF-8 (Accessed on 02.09.2021)

65. World Bank (2021) Breathing uneasy: Regional response to air pollution in South Asia. Available from: https://live.worldbank.org/breathing-uneasyregional-response-air-pollution-south-asia (Accessed on 02.09.2021)

66. World Health Organization (WHO) (2016) Ambient air pollution. A global assessment of exposure and burden of disease. Available from: https://apps.who.int/iris/handle/10665/250141(Accessed on 24.07.2021)

67. World Health Organization (WHO) (2019) Health consequences of air pollution on population. Available from: https://www.who.int/news/item/ (Accessed on 04.07.2021)

68. World Health Organization (WHO) (2021) Air Pollution. Available from: https://www.who.int/health-topics/air-pollution (Access 04.07.2021)

\section{Figures}

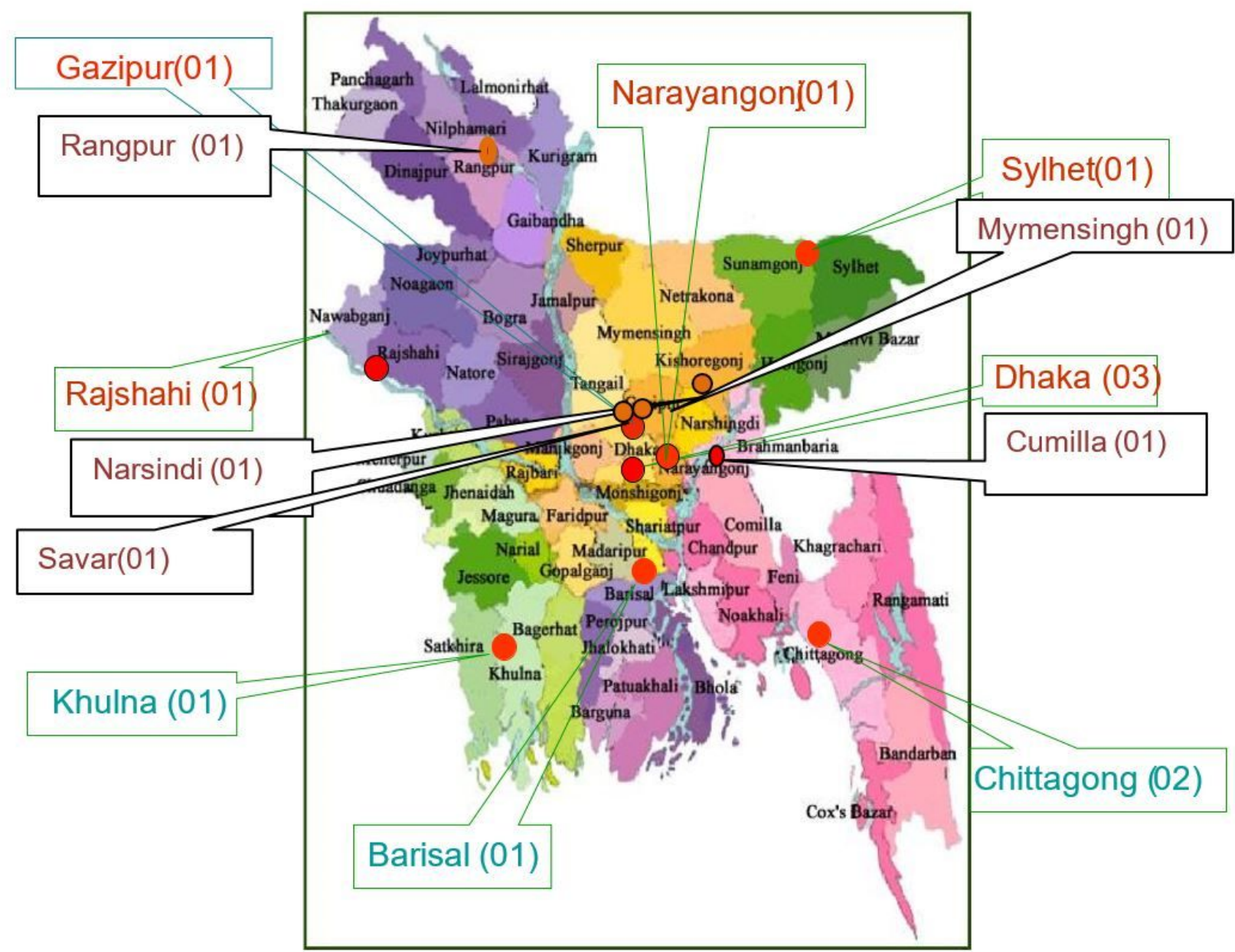

Figure 1

Locations of Continuous Air Monitoring Stations (CAMS) in Bangladesh (CASE, 2018) 


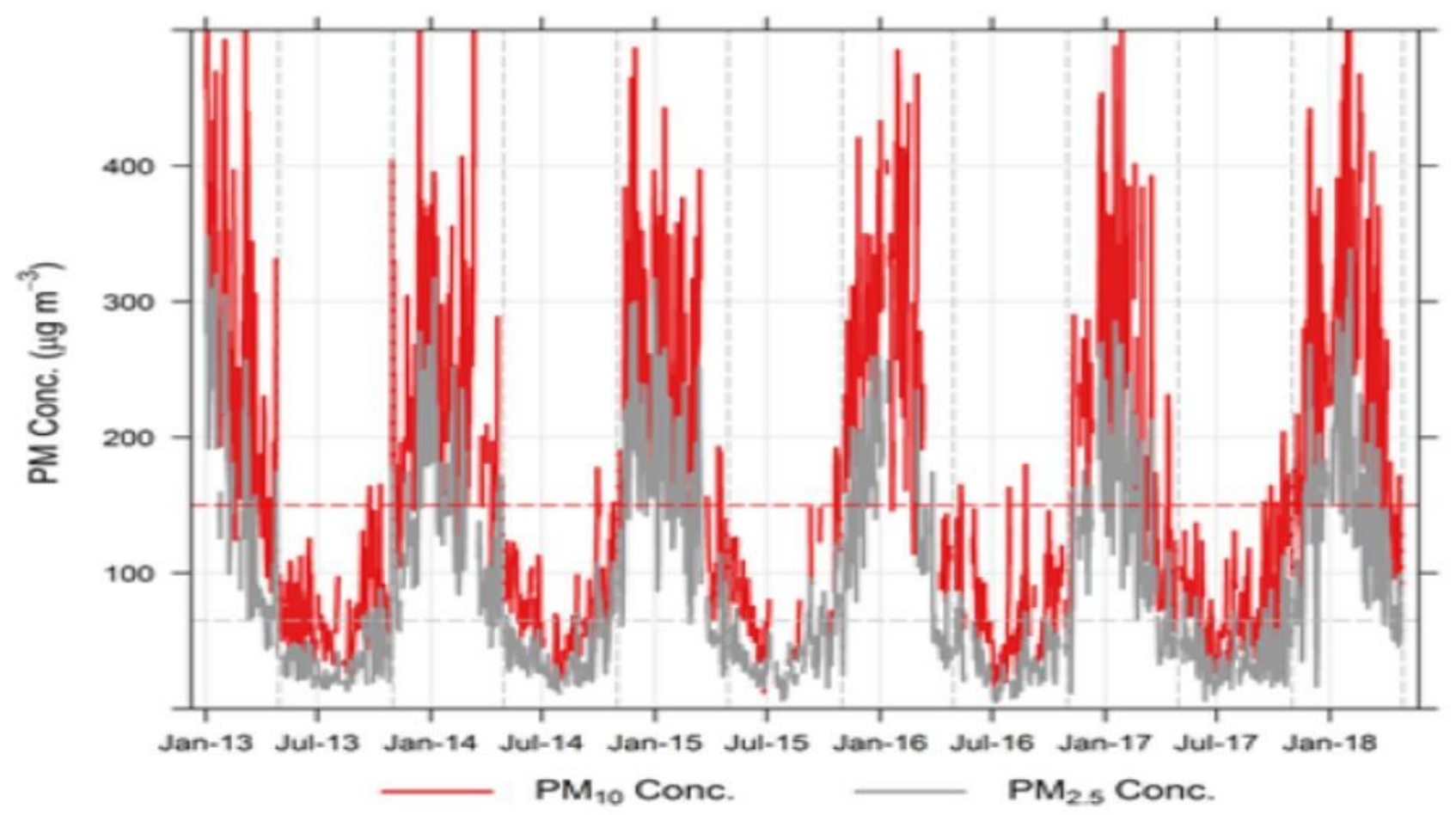

Figure 2

Distribution of $\mathrm{PM}_{10}$ and $\mathrm{PM}_{2.5}$ from 2013 to 2018 in Dhaka

Source: Reference CASE, 2018. 